Article

\title{
How Knowledge Sharing Culture Can Become a Facilitator of the Sustainable Development in the Agrifood Sector
}

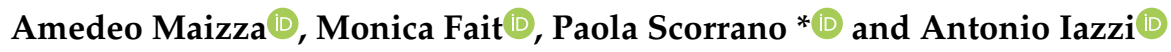 \\ Department of Management, Economics, Mathematics and Statistics; University of Salento, 73100 Lecce, Italy; \\ amedeo.maizza@unisalento.it (A.M.); monica.fait@unisalento.it (M.F.); antonio.iazzi@unisalento.it (A.I.) \\ * Correspondence: paola.scorrano@unisalento.it; Tel.: +39-0832-298992
}

Received: 9 January 2019; Accepted: 1 February 2019; Published: 13 February 2019

\begin{abstract}
This article proposes a managerial vision of the sustainability planning of a territory. The main assumption is that the sustainable development policies of a territory oriented to the agrifood sector cannot be separated from the participation in the decision-making process of the stakeholders as well as the sharing of objectives and development paths. The paper offers an innovative perspective because it proposes a model in which sustainable development can be improved not only through the attention to the production process, but also through the Knowledge Sharing Culture, which allows the inclusion of social innovation. This model was tested on the companies participating in the Italian Agri-food Protection Consortia as they represent an example of a managerial vision of the territory use and also because they integrate the protection of specific agricultural and food production with the commitment of entrepreneurs and families who share a common growth path. The empirical results show that Knowledge Sharing Culture can become a facilitator of the sustainable development of the territory when it is activated along specific "determinants" and related "operative activities" that transform the Knowledge Sharing Culture into a driver of social innovation oriented to the sustainability of businesses and their territory.
\end{abstract}

Keywords: Knowledge Sharing Culture; sustainable development; agrifood sector; value co-creation

\section{Introduction}

The relationship between business and land - the traditional driver of the pursuit of sustainable competitive advantages [1-3] can determine the relational and participatory developmental paths [4-9] through which an environmental, economic, and social identity can be built [10-12]—an identity that is unique for businesses and their territory. The most natural path to achieving these significant results is the emergence of collaborative relationships among companies [13-16] operating in the same geographical area.

Italy has always represented a fertile land of different aggregative formulas, which, also depending on the legal typology assumed, take on different names (districts, consortia, cooperatives, business networks, business groups, supply chain agreements), despite having similar goals, collaborative relationships between companies, operating rules, and controls [17].

Among these aggregative formulas, a particularly important position is held in the agrifood sector by the Protection Consortia-systemic realities that have been formed and consolidated through a process of sharing visions, missions, and principles by entrepreneurs with the ambition and desire to make a land, its products, and its values known. Many of these networks (of which the best-known cases include Prosciutto di Parma, Parmigiano Reggiano, Chianti, Asti, etc.) have generated important forms of sustainable development and "widespread value" for the communities from which they 
emerged [18]. The product brands are, in fact, the names of the territories to which they belong, hence the "brand-land" relationship [19-21]; that is, those aggregative territorial typologies that developed through the logic of the self-generation of well-being, conservation, and enhancement of the territory thanks to the sharing of "behavioral values" (through actions of moral suasion) and "product values" (with appropriate quality control), thus sharing practices, methods, values, and knowledge.

In fact, knowledge is a driver of the "traditional" value of the brand-land, and thus of the sustainable development of territories that are suitable for the agrifood economy. Consequently, knowledge sharing, considering its nature as a "fluid mix of framed experience, values, contextual information and expert insights" [22] (p. 5), represents a potential on which strategic common actions can be based. knowledge sharing, being a process of social interaction that involves knowledge, experiences, and skills of individuals working in an organization [23], implies the creation of new knowledge [24], helps organizations identify best practices, promotes new ideas and organizational learning [25,26], and promotes shared achievement of management objectives [27]. The innovative processes, instead, pass through the sharing of the knowledge resources of a company with other subjects with which it is related [28,29]. In fact, the existence of a network of relationships that combines the various cognitive assets influences the creation of value for the participating companies [30].

Starting from these reflections, this work therefore intends to answer the following research questions.

RQ1: In which determinants (defined below) should knowledge sharing between area networks and land be realized with a view to co-creating sustainable development?

RQ2: In which directions should policies be devised for this co-creation?

The approach focused on the strategic potential of knowledge sharing seems to us to be a different declination of the "business-land" relationship adopted in the agrifood sector, which is traditionally read from the sole perspective of environmental protection. This approach, however, is adequate if we wish to support a shared and synergistic development, which, going beyond that reductionist view, obtains a holistic perspective that also considers socioeconomic development.

To understand the dynamics of sharing [31] and to support our claims, we propose a model based on a combination of social cognitive theory $[32,33]$ with Nahapiet and Ghoshal's theoretical model of social capital [20,22], tested on companies in the Italian Agri-food Protection Consortia to discuss our research questions.

The social capital is interpreted as the ability of the actors to understand the relevance of the advantages deriving from participation in social interaction mechanisms whereas the socio-cognitive perspective regards the role of the expectations of the results in the exchange of knowledge. Therefore, the conceptual and empirical model developed on the two dimensions provides a systemic view of the pre-conditions necessary for the adoption of a knowledge sharing strategy oriented to the co-creation of sustainable development and bridges the gap linked to the absence of operational tools, which is useful to understand the existence of adequate environmental conditions for the implementation of these strategies in business networks.

To discuss our research question, the study is organized as follows: We first provide the essentials of the conceptual and theoretical background of our proposal by illustrating the link between knowledge sharing, social capital, and socio-cognitive perspective and a concise focus on the theoretical notion of the complex value of agrifood aggregations. Then, we present the methodological approach adopted, highlighting elements useful to the subsequent discussion where we analyze how knowledge sharing becomes a facilitator [34-37] in the co-creation of sustainable value when relative strategies are activated following certain policies and specific operational interventions. Finally, we provide the conclusions and we highlight the main managerial and research implications. 


\section{Theoretical Background}

\subsection{Knowledge Sharing, Social Cognitive Theory and Social Capital Theory}

The literature has demonstrated the important role of knowledge sharing that involves knowledge, experiences, and skills of individuals working in an organization [23,25-27,38].

Various academic contributions [36,39,40] and practitioner-oriented publications [41,42] have suggested that access to new resources of knowledge is one of the most important consequences of social capital. In fact, it is the process of social interaction within a given context that develops knowledge $[43,44]$. In this perspective, many studies have interpreted social capital as the driver that facilitates access to knowledge, as it creates an environment characterized by mutual trust and appreciation of the knowledge of others $[33,45-48]$ and nurtures social interactions and immersion in practice [49-52]. The model that most contributed to the understanding of the link between social capital and knowledge sharing is the one proposed by Nahapiet and Ghoshal (1998). For the authors, social capital is characterized by the combination of three dimensions: The structural dimension, represented by those interpersonal relationships that characterize a community; the cognitive dimension, which includes those factors of the social organization that generate a shared representation of their community; the relational dimension, which concerns the relationships that are created through a continuous system of interactions and generates a type of norm-trust, reciprocity, and solidarity. The three dimensions are interrelated and there is a kind of causal sequence between them that makes the social capital productive of collaborative behaviors that generate mutual benefits within a community [53] and the achievement of otherwise impossible objectives.

As the social cognitive theory suggests, human behavior is based on triadic, dynamic, and reciprocal interaction of personal factors, behavior, and the social network system. The theory is based on the assumption that the learning of individuals also depends on the observation of the behavior of others. The reproduction of an observed behavior depends on determinants influencing the quality of the decisions taken [54-59]. Naturally, the individual's will is required to direct his actions towards certain activities, as well as the ability to take appropriate behaviors (known as self-regulation) also based on a self-evaluation of the robustness of one's own knowledge. This is all the more useful when the individual is part of a group of people acting individually (personal expectations) or jointly (community expectations) to pursue a common goal. In this circumstance, it is believed that individuals can benefit from the knowledge and skills of others to fill up their specific gaps, sharing their information to make new knowledge. Furthermore, the exchange of information/knowledge is facilitated precisely by the existence of the network; in some cases, it may be structured and codified (for example, the use of shared language, common technology, etc.). A further element of facilitation of knowledge sharing is represented by the fact that individuals usually belonging to a network (for example, a consortium of companies) operate in the same sector, or in similar or complementary sectors, and share common interests and objectives. By observing their behavior, the best practices thus emerge, which results in voluntary and conscious high learning levels (benchmarking theory) [60,61].

\subsection{The Impact of Protection Consortia on the Land of Origin}

The choice of the Italian Agri-food Protection Consortia as a research area is based on the economic and social relevance that these organizations have on the land and on their international reputation. Created to protect the production of specific food items, the consortia presently represent the commitment of entrepreneurs and families who share a common path of growth. The communication activities they perform are increasingly important tools in promoting the specific quality and culture of a geographical area. They are thus natural meeting places for knowledge, experiences, and skills, through whose exchange competitive advantage and sustainable development can be derived. It is therefore evident that the network of social, personal, and value-sharing relationships, whether formal or informal, that characterize the consortia fully responds to the creation of a system of territorial relations in which the exchange of tangible or virtual resources, and particularly of knowledge, 
facilitates the co-creation of value for businesses and the land [35,62]. These systemic aggregative formulas ultimately represent the best practices of business combinations that have contributed to the sustainable development of the local land through the production of specific and "typical" foodstuffs.

By "typical" agricultural food production, we refer broadly to all those products characterized by a close link with their land of origin, which is often explained and enhanced by certification marks—such as, for example, the Registered Designation of Origin, Protected Designation Origin, Protected Geographical Indication-. These involve a natural link with the country of origin [63-68] and with the production traditions that emphasize the benefits of the "made in" effect [20]. For this reason, these goods, in addition to stimulating the need for direct knowledge of places, can become products whose value transcends their intrinsic usefulness, since they determine effects tied to the sensations [69] that they can generate. The consortia protect products that have a profound link with their respective places of production, because the features of typicality that characterize them are not replicable or "exportable" outside that specific context $[70,71]$. The identity of a land (place-identity) [72,73] is thus a direct consequence of its specific vocation (place-personality).

Italy has always been the nation with the greatest number of Designation of Origin and Geographical Indication products; these are verified by the Protection Consortia. Consumer sales of these products have grown continuously over the years, even throughout the economic crisis and the consequent contraction of consumer spending potential. In the 2016 Ismea-Qualivita Report [74], the production value stood at around seven billion euro, and was geographically divided as follows: $€ 3,808,000$ or $58 \%$ in the northeast, $€ 1,818,000$ or $27 \%$ in the northwest, $€ 245,000$ or $4 \%$ in the center, $€ 412,000$ or $6 \%$ in the south, and $€ 335,000$ or $5 \%$ on the islands. The value of exports has also shown a continuous increasing trend and is estimated at $€ 3.4$ billion to a range of countries worldwide. These values demonstrate the relevance of the agrifood sector, in which consortia have a considerable importance for the economy of the country of origin. They contribute to sustainable development as they are aggregations of deeply rooted enterprises to the territory and are dedicated to the preservation and enhancement of geographical areas, and not "corsair enterprises", disconnected from the contexts in which they temporarily operate [32].

\section{Materials and Methods}

\subsection{Interpretative Framework}

The methodological approach adopted in this paper is based on the interpretation of the land as a social organization [75], where the relationships hold between structures and infrastructures. These relationships derive from the representation of the territory as a viable system that is able to create value for the other entities of the context (public groups of governments, communities, investors, natural environment, future generations, non-human species), thus defining the essential conditions for a sustainable equilibrium [76]. In these relationships, each factor is valorized and generates appeal for the land and the enterprises that have a relationship with it [75]. From the point of view of the synergic relationship between the agrifood sector and the land, the consortia are a unity made up of local production systems, different types of actors, culture, and a shared acquisition process. They are a social phenomenon that supports and extends a normative and behavioral social capital [76-80], understood as a complex of cultural, historical, political and social elements, behavioral rules, shared values, and learning. The territory and consortia thus share a tendency towards sustainability based on the traditional dimensions of sustainable development: The economic, social, and environmental [1].

From this perspective, this work aims to identify the "determinants" (and the related "descriptive variables") that promote the exchange of knowledge (RQ1) and the possible "operative activities" (RQ2), so that knowledge sharing policies can become drivers of social innovation oriented towards the sustainability of companies and territories.

The interpretative framework proposed here, which combines social cognitive theory [56,81] with Nahapiet and Ghoshal's theoretical model of social capital [40], makes it possible to identify 
ideal (theoretical) inputs adapted to the specific research context. We consider the combination of the two theories to be of fundamental importance, as it allows us to provide a picture of the companies' behavior in the phase of interaction with the environment in question.

To define this initial theoretical assumption and to then carry out the empirical verification, we proceeded as follows:

a) We described the three dimensions (economic, social, and environmental) in which sustainable development is characterized by identifying the determinants;

b) we identified, through a process of logical deduction, the descriptive variables of the determinants;

c) for each of the variables, we identified the operative activities carried out by the companies operating in the consortia (see Figure 1);

d) we designed and administered the questionnaire;

e) we calculated the results with logit analysis and the correlation matrix;

f) we identified the operative activities deemed relevant by the companies for a joint sustainable development of the "business-land".

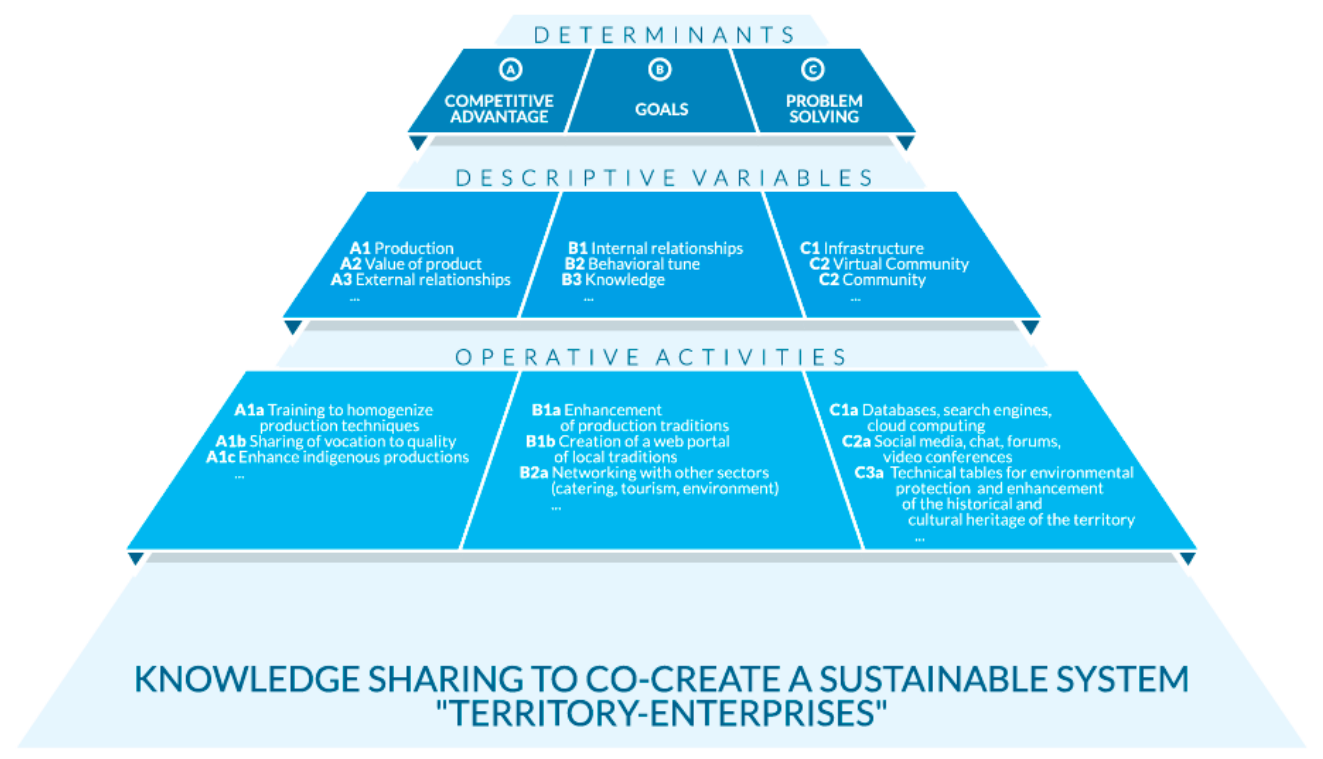

Figure 1. Representation of the logical process of analysis (Source: our elaboration).

To clarify the economic dimension of sustainable development, reference has been made to the concept of the outcome expectations fulcrum of social cognitive theory [56]. These involve the consequences deriving from the assumption of a particular behavior and the perceived relative advantage [80], both from the individual perspective and the community perspective [82-84]. From the business perspective, any behavior must generate a competitive advantage as its main effect; the determinant is thus represented by the competitive advantage (A), which we take to have the following descriptive variables: Increasing the level of productive specialization: Production (A1); increasing the value of the agrifood product: Value of product (A2); increasing and stabilizing relationships between territorial stakeholders: External relationships (A3); facilitating the survival and strategic growth of the consortium: Growth (A4); enriching cognitive heritage oriented toward the specific circumstances of the land: Cognitive heritage (A5).

The identification of the determinant of the social dimension begins with the consideration that both companies and territories are a source of social capital, as they represent a complex of cultural, historical, political, and social elements, rules of behavior, and the sharing of values and learning $[77-80,85,86]$. This implies that this determinant is represented by the creation of relationships oriented towards the sharing of common objectives or goals (B). In line with the model of Nahapiet and 
Ghoshal [40], which provides a multidimensional (structural, cognitive, and relational) representation of social capital, the descriptive variables of this determinant are taken to be: The creation of internal cohesion, as this is an expression of the propensity of companies to maintain and expand relations within the network (internal relationships, B1); adoption of behaviors consistent with the aims of the consortium and the land through supply-chain networks (behavioral tune, B2); the design of an environment favorable to the generation of an epistemic community that shares specific fields of knowledge (knowledge, B3); and reinforcement of the sense of belonging to a community that shares culture, traditions, and behavioral standards (identity, B4).

The environmental dimension of sustainable development here coincides with social environmental capital, an expression of the sense of belonging to a community, which takes the form of relationships between companies and actors, for the purpose of preservation, protection, and enhancement of the land of belonging. The determinant of this dimension-problem solving (C) - was found in the desire to face and solve common problems in view of environmental development also through the circular economy. In this regard, the cognitive value of social capital is taken as being important, which translates into the sharing of rules and behaviors aimed at defending territorial characteristics and related culture [49,51]. In particular, in the present digital era, it is of utmost importance to provide a learning environment free from constraints, such as time, place, and learning mode [39]. In this perspective, the descriptive variables identified are: Facilitating access to information (infrastructure, C1); creating virtual work groups (virtual community, C2); and the creation of communities, such as physical work groups (community, C3).

For each descriptive variable, we then identified specific operative activities through the direct observation of the consortia's websites and documents they have published, as well as social networks, in order to extrapolate the activities that these observed realities have in the processes of valorization of their products, which may involve the land.

\subsection{Sample}

Our interpretative model was tested using the survey method for data collection $[87,88]$. The questionnaire was structured to consider the identified determinants and to prepare the questions so that the respondents could express their judgment on a Likert scale from 0 (not important) to 5 (very important), for both the descriptive variables and the operative activities. From January to March 2018, 442 questionnaires were distributed by e-mail to the directors of companies belonging to four agrifood consortia in the most relevant areas of the Italian economy: Wine, dairy, ham, and fruit-growing, considering the period of activity and the number of consortium members. Being an exploratory research, conducted on a selected sample, the technique of convenience sampling was applied and a total number of 60 properly completed, valid questionnaires were collected, considered, and analyzed. Table 1 shows the information of the respondents.

Table 1. Demographic information (Source: our elaboration).

\begin{tabular}{ccc}
\hline Requested Information & \multicolumn{1}{c}{ Range } & Response Rate \\
\hline \multirow{3}{*}{$\begin{array}{c}\text { Years of membership } \\
\text { in a consortium }\end{array}$} & Less than 10 years & $17 \%$ \\
\cline { 2 - 3 } & From 10 to 20 years & $26 \%$ \\
\cline { 2 - 3 } & From 21 to 30 years & $21 \%$ \\
\cline { 2 - 3 } Employees & More than 30 years & $36 \%$ \\
\cline { 2 - 3 } & From 10 to 49 employees & $85 \%$ \\
\cline { 2 - 3 } & From 50 to 250 employees & $13 \%$ \\
\hline \multirow{2}{*}{ Turnover } & More than 250 employees & $2 \%$ \\
\cline { 2 - 3 } & Less than 2 million $€$ & $83 \%$ \\
\cline { 2 - 3 } & From 2 to 10 million $€$ & $15 \%$ \\
\hline
\end{tabular}




\subsection{Methodology}

Our methodology employed a logit model, with calculations performed by SPSS (Statistical Package for Social Science) [24,89], to examine the correlation between the propensity to exchange knowledge (dependent variable) and the input variables described above (independent variables). In the logit model, independent variables are combined into a linear function that estimates the logarithm of the relationship between the probability that an event will occur and the probability that it will not occur (in our case, the probability of exchanging knowledge and the probability of not exchanging knowledge).

The forecasting function takes the typical following form:

$$
\operatorname{Ln}[\mathrm{PKS} /(1-\mathrm{PKS})]=\mathrm{a}+\mathrm{BX}+\mathrm{E}
$$

where: Ln is for the natural logarithm, PKS is the probability of exchanging knowledge, (1 - PKS) is the probability of not exchanging knowledge, a is the constant, B is the vector of the coefficients of the dependent variable, $X$ is the vector of the independent variables (in our case, the set of variables from $A$ to $C 3$ ), and $E$ is the error.

In the analysis carried out with SPSS, vector B is represented in the table "Equation variables" (see Table 4) in which, for each coefficient, the significance level and the value of the odd ratio are also indicated [Exp (B)]. It is a relative probability measure, since it expresses the probability of exchanging knowledge in the presence of each covariate with respect to the probability of exchanging knowledge in the absence of the same covariate. A method, therefore, that has proven suitable for identifying, among the independent variables, the predictive variables, i.e., those that have a greater explanatory power, as well as to estimate the probability of the influence of each of the covariates with respect to the probability of the propensity to sharing knowledge and the potential links with the observed phenomenon.

The chi-square test (see Table 2) showed an insignificant difference of 0.742 , for which it is possible to accept the null hypothesis of a good adaptability of the data to the model. The significance of the model is also demonstrated by the classification table (Table 3), which shows that the model correctly classifies $71.7 \%$ of the observations.

Table 2. Hosmer-Lomeshow significance test (Source: our elaboration).

\begin{tabular}{cccc}
\hline Phase & Chi-Square & Gl & Sign. \\
\hline 1 & 5.148 & 8 & 0.742 \\
\hline
\end{tabular}

Table 3. Classification table (Source: our elaboration).

\begin{tabular}{|c|c|c|c|c|c|}
\hline \multirow{5}{*}{ Phase 1} & \multirow{2}{*}{\multicolumn{2}{|c|}{ Observed }} & \multicolumn{3}{|c|}{ Expected Propensity to Sharing Knowledge (SK) } \\
\hline & & & 0 & 1 & Percent Correct \\
\hline & \multirow{2}{*}{ A00 Propensity to SK } & 0 & 22 & 8 & $73.3 \%$ \\
\hline & & 1 & 9 & 21 & $70.0 \%$ \\
\hline & Overall percentage & & & & $71.7 \%$ \\
\hline
\end{tabular}

\section{Results}

The logit model was thus able to identify only three significant predictive variables from the independent variables-those that have explanatory power greater than the observed phenomenon. Considering the level of significance $(p<0.050)$, Table 4 shows that the predictive variables are: Competitive advantage ( $\mathrm{A} ; p=0.032)$; goals $(\mathrm{B} ; p=0.040)$; and problem solving $(\mathrm{C} ; p=0.050)$. Therefore, it is possible to state that the probability that accompanies the use of knowledge sharing is mainly related to determinants, with which we describe the three dimensions (economic, social, and environmental) of sustainable development in the model. This allowed us to answer the first research 
question (QR1) by identifying the management areas in which the exchange of knowledge must take place to co-create sustainable development.

Table 4. Dependent variables: Propensity to sharing knowledge (Source: our elaboration).

\begin{tabular}{ccccccc}
\hline Variables & B Coeff. & S.E. & Wald & g1 & Sign. & Exp (B) \\
\hline (A) Competitive Advantage & -0.479 & 0.223 & 4.623 & 1 & 0.032 & 0.619 \\
A1 Production & -0.257 & 0.289 & 0.792 & 1 & 0.373 & 0.773 \\
A2 Value of product & 0.202 & 0.207 & 0.949 & 1 & 0.330 & 1.223 \\
A3 External relationship & 0.092 & 0.278 & 0.109 & 1 & 0.741 & 1.096 \\
A4 Growth & -0.375 & 0.322 & 1.358 & 1 & 0.244 & 0.687 \\
A5 Cognitive Heritage & 0.541 & 0.345 & 2.467 & 1 & 0.116 & 1.719 \\
(B) Goals & -0.532 & 0.260 & 4.197 & 1 & 0.040 & 0.587 \\
B1 Internal relationship & 0.055 & 0.194 & 0.079 & 1 & 0.778 & 1.056 \\
B2 Behavioral tune & -0.587 & 0.338 & 3.027 & 1 & 0.082 & 0.556 \\
B3 Knowledge & -0.127 & 0.183 & 0.480 & 1 & 0.488 & 0.881 \\
B4 Identity & -0.052 & 0.241 & 0.046 & 1 & 0.830 & 0.949 \\
(C) Problem solving & 0.617 & 0.314 & 3.856 & 1 & 0.050 & 1.854 \\
C1 Infrastructures & 0.128 & 0.199 & 0.414 & 1 & 0.520 & 1.137 \\
C2 Virtual community & -0.024 & 0.217 & 0.013 & 1 & 0.910 & 0.976 \\
C3 Community & 0.124 & 0.188 & 0.431 & 1 & 0.512 & 1.132 \\
Constant & 5.677 & 3.791 & 2.242 & 1 & 0.134 & 292.034 \\
\hline
\end{tabular}

Logistic Regression

Number of observations $=60$

Nagelkerke R-squared $=0.281$

Log likelihood $=68.969$

In Table 4, we can also see the variables of the model that have a minor significance in the relationship with knowledge sharing. Nevertheless, we wanted to verify if these variables can contribute indirectly to the proposed framework. Therefore, the correlation between the three predictor variables (determinants) and the remaining variables was analyzed to verify if these, in a systemic perspective, can become the descriptive variables along which a strategy oriented toknowledge sharing culture could be built (RQ2). Thus, an analysis of the correlation matrix (see Table 5) between the identified variables was carried out. This method makes it possible to check whether there is a dependency relationship between the variables. The comparison was performed by means of the Bravais-Pearson correlation coefficient (between -1 and 1), which is able to measure the intensity of the relationship. Two quantitative variables are positively correlated if they vary in a concordant way; the increase [decrease] of one increases [decreases] the other, which is negatively related if they vary in a discordant manner. Two characters, therefore, seem to agree if the differences from the average tend to be of the same sign while they are discordant if such discord tend to be of the opposite sign. From Table 5, it is clear that there is a correlation between the determinants identified in the model. 
Table 5. Correlation matrix (Source: our elaboration).

\begin{tabular}{|c|c|c|c|c|c|c|c|c|c|c|c|c|c|c|c|c|}
\hline & & $\begin{array}{l}\text { Competitive } \\
\text { Advantage }\end{array}$ & Production & $\begin{array}{l}\text { Value of } \\
\text { Product }\end{array}$ & $\begin{array}{c}\text { External } \\
\text { Relationships }\end{array}$ & Growth & $\begin{array}{l}\text { Cognitive } \\
\text { Heritage }\end{array}$ & Goals & $\begin{array}{c}\text { Internal } \\
\text { Relationships }\end{array}$ & $\begin{array}{c}\text { Behavioral } \\
\text { Tune }\end{array}$ & Knowledge & Identity & $\begin{array}{c}\text { Problem } \\
\text { Solving }\end{array}$ & $\begin{array}{c}\text { IT } \\
\text { Infrastructures } \\
\end{array}$ & $\begin{array}{c}\text { Virtual } \\
\text { Community } \\
\end{array}$ & Community \\
\hline $\begin{array}{l}\text { Competitive } \\
\text { Advantage }\end{array}$ & $\begin{array}{l}\text { Corr. di Pearson } \\
\text { Sign. (a due code }\end{array}$ & & & & $\begin{array}{l}0.294 * \\
0.023\end{array}$ & & $\begin{array}{l}0.299 * \\
0.020\end{array}$ & $\begin{array}{l}0.325^{*} \\
0.011\end{array}$ & & & & & $\begin{array}{l}0.338^{*} \\
0.008\end{array}$ & $\begin{array}{c}0.351^{\text {** }} \\
0.006\end{array}$ & $\begin{array}{l}0.295 * \\
0.022\end{array}$ & \\
\hline Goals & $\begin{array}{l}\text { Corr. di Pearson } \\
\text { Sign. (a due code }\end{array}$ & & & & & & $\begin{array}{c}0.470^{* *} \\
0.000\end{array}$ & & & $\begin{array}{c}0.333 * * \\
0.009 \\
\end{array}$ & & $\begin{array}{c}0.432 \text { ** } \\
0.001\end{array}$ & $\begin{array}{l}456 * * \\
0.000 \\
\end{array}$ & & & \\
\hline $\begin{array}{c}\text { Problem } \\
\text { solving }\end{array}$ & $\begin{array}{l}\text { Corr. di Pearson } \\
\text { Sign. (a due code }\end{array}$ & $\begin{array}{l}0.338 * * \\
0.008\end{array}$ & & & & $\begin{array}{c}0.339 * * \\
0.008\end{array}$ & & $\begin{array}{l}0.456 \text { ** } \\
0.000\end{array}$ & $\begin{array}{l}0.331 * * \\
0.010\end{array}$ & $\begin{array}{l}0.466 * * \\
0.000\end{array}$ & $\begin{array}{l}0.603 * * \\
0.000\end{array}$ & & & & $\begin{array}{l}0.654^{* *} \\
0.000\end{array}$ & \\
\hline
\end{tabular}

*. The correlation is significant at level 0.05 (two-tailed); **. The correlation is significant at level 0.01 (two-tailed). 
In fact, competitive advantage (A) is correlated with both goals (B) (0.325) and problem solving (C) (0.338); this bond is strengthened when we observe the correlation between goals (B) and problem solving (C) (0.456). The really interesting aspect, however, lies in the link between the determinants and the descriptive variables as well as in the link between the descriptive variables and the operative activities carried out by the companies. Focusing our attention on the individual determinants, we can make the following reflections that allow us to respond to RQ2:

1) Competitive advantage is related to both external relationships (0.294) and cognitive heritage (0.299). On the one hand, this highlights the importance of stabilizing relations with local actors. The drivers considered most significant are represented by operative activities, such as events and cultural initiatives to rediscover local traditions; on the other hand, the importance of enriching the cognitive patrimony is highlighted through the training of professional figures with skills that transverse to the sector and to local development issues. The strengthening of relations then passes through the sharing of objectives (goals; 0.325 ) that are not traditional, but innovative (note that the variables, production and value of product, are not correlated). This is confirmed by the correlation with the descriptive variables of infrastructure (0.351) and virtual community (0.295). With regard to the first variable, companies report that access to and dissemination of knowledge can be facilitated by the use of databases, search engines, cloud computing, and others. Equally interesting are the innovative tools related to the virtual community variable, since companies consider social media, messaging applications, forums, video conferences, and similar technologies as instruments that fuel comparison and make it possible to increase recognition in the final consumer of the historical productive traditions and, consequently, the fame of the land's products.

2) Goals: The correlation matrix shows how the process of knowledge sharing aimed at sustainable development requires, according to the companies, the creation of a network of relationships capable of: a) Facilitating the enrichment of the cognitive heritage, orienting it to the specificities of the land (cognitive heritage; 0.470 ), in particular by training professionals with skills transversal to the sector and to local development issues; b) generating behaviors consistent with the aims of the consortium and the land (behavioral tune; 0.333 ); for this purpose, the membership of a supply chain network and of other networks, which may include local catering companies, companies in the tourism sector, national parks, and similar, is perceived as useful. Moreover, the exchange of knowledge aimed at the sharing of common objectives facilitates the growth of the sense of belonging to a community that shares the culture, traditions, and rules of behavior (identity; 0.432), which lead to the affirmation of identity and to the conception of or strengthening of a territorial brand.

3) Problem solving: Solving common problems with a view to environmental development is coherent: a) With individual expectations of competitive advantage (competitive advantage; $0.338) ; b$ ) with the expectations of the community represented by the survival and growth of the consortium as a phenomenon rooted in the land (growth; 0.339 ; c) with the internal relationships necessary for an efficiency of sharing (internal relationships; 0.331). It is also interesting to note that companies consider it essential for the resolution of common problems and for enhancing historical production traditions through: 1) The creation of a website describing local traditions (goals; 0.456); the creation of a supply chain and other networks (behavioral tune; 0.466); 2) the generation of an epistemic community that shares specific fields of knowledge through forms of e-learning on websites for the entire community (knowledge; 0.603 ); 3 ) the sharing of information through the creation of forums, messaging applications, and social media (virtual community; 0.654) that facilitate comparison and promote shared planning.

These reflections suggest that a knowledge sharing culture oriented to sustainability is characterized by a process where the initial input to the exchange is the search for a competitive advantage in which the sharing of objectives becomes fundamental, which then facilitates the resolution 
of common problems. The descriptive variables, then, become intermediate facilitators because they represent specific fields of knowledge on which to build an environment favorable to the generation of an epistemic community that shares knowledge. The tools and the operative activities represent the actions that companies consider most effective for the co-creation of sustainable development founded on the genesis of a common knowledge heritage.

\section{Discussion}

The empirical application of our model shows that knowledge sharing is undoubtedly a strategy that can strengthen the ecosystem of a land and make stakeholders co-creators of sustainability. It is perceived by companies as a facilitator [37,90-92] of such development and therefore as an instrument of social innovation when activated by a virtuous circle.

This is a logic that starts from the expectations of both individual companies and communities of companies (competitive advantage), but is also capable of contextually considering the need to strengthen the social dimension (goals) through the creation of identity and the orientation of cognitive heritage towards the specificities of the land, as well as the consolidation of external relationships and internal relationships to face and solve common problems (problem solving). This virtuous circle finally finds-in the sharing of a common language and through the creation of infrastructures and a virtual community-a means to broaden the comparison and complete the process of co-creation. These variables are guidelines on the basis of which policies can be activated that aim at co-creating sustainability, though the most interesting aspect concerns the operational tools indicated by the respondents. Beyond the consolidated sharing of cultivation and production methods acquired by the companies in the protection consortia, they consider the following to be fundamental in achieving a competitive advantage: The realization of cultural events and initiatives for the rediscovery of local traditions and productions, investment in technology to improve production techniques, and to train professionals with skills transversal to the sector and to local development issues. At the same time, they consider it important to broaden the social dimension of the objectives sharing, fueling the sense of a community of actors exchanging culture, traditions, and rules of behavior, activating networks outside the supply chain with sectors that share the culture of the territory they belong to (restaurants, tourism, national parks, nonprofit organizations, etc.) and using e-learning formulas created through a dedicated website for the entire community. From these paths, an identity is born and consolidated and must be communicated and enhanced through the creation or strengthening of a territorial brand. Equally interesting are the operative activities that are considered important for the process of solving common problems. The adoption of a common language can be coordinated with: The creation of a website that promotes the traditions of the land, e-learning resources on websites for the entire community, and the sharing of information through virtual communities that facilitate comparison and promote shared planning.

A governance attentive to the multidimensional needs of the land must thus not neglect to consider the needs and proposals that come from the companies operating within it, especially when these are representative of the culture of a territory, as in the case of companies that belong to a protection consortium.

\section{Conclusions}

This study combines managerial and research implications, throwing light on multi-disciplinary research streams with a potential impact upon territorial development.

The results of our survey suggest that a policy oriented towards the sustainability of the territory-enterprises system must rely on the development and strengthening of a knowledge sharing culture. The challenge, therefore, is to strengthen the ability of network governance to activate operational lines that make the "competitive advantage-goals—-problem solving" relationship no longer a random mechanism, but one that is well-researched and well-defined. In this way, in fact, it can represent a combination of the expectations (not only economic) of the productive fabric, the sharing of 
objectives, the strengthening of relationships between enterprises, and the propensity to participate in environmental planning through the comparison and sharing of a common language. This condition, of course, activates a virtuous circle, thanks to which improvements in systemic performance generates attractiveness, a need to improve company management, and an increase in value for the actors in relation with them. Ultimately, it is capable of conveying the culture of knowledge sharing in areas (such as the agrifood sector) perhaps not very accustomed to either these means of sharing intangible resources or to sharing the structural elements of the management processes.

The limits of the work lie in the fact that the knowledge sharing culture is still an ongoing process. The exploratory nature of the work suggests that the proposed discussions can be considered as only preliminary. In fact, the predictive nature of the determinants and their link with descriptive variables suggest that the knowledge sharing culture is perceived as a natural driver of the co-creating process of sustainable development. Relevant suggestions about tools and operative activities were included to address and favor the process of knowledge sharing. In our opinion, the proposed framework introduces adequate general interpretation schemes for the investigation of the importance of a knowledge sharing culture in the co-creating process of sustainable development, in part filling the gap linked to the absence of operational tools adequate for understanding the existence of environmental conditions for the implementation of these strategies in business networks. A future contribution to research could come from the expansion of the sample in the sector analyzed and also from the application of the model in other sectors.

Author Contributions: This paper is the result of common reflections. A.M. wrote Sections 1 and 2.2; M.F. wrote Section 3; P.S. wrote Sections 2.1 and 4; A.I. wrote Sections 5 and 6.

Funding: Authors used their University funds for covering the costs to publish in open access.

Conflicts of Interest: The authors declare no conflict of interest.

\section{References}

1. Barile, S.; Saviano, M.; Polese, F.; Di Nauta, P. Il rapporto impresa-territorio tra efficienza locale, efficacia di contesto e sostenibilità ambientale. Sinerg. Ital. J. Manag. 2013, 90, 25-49.

2. Dyer, J.H.; Singh, H. The relational view: Cooperative strategy and sources of inter-organizational competitive advantage. Acad. Manag. Rev. 1998, 23, 660-679. [CrossRef]

3. Costabile, M. Il capitale relazionale: Gestione delle relazioni e della customer loyalty; McGraw-Hill: Milano, Italy, 2001.

4. Fotino, F; Calabrese, M.; Lettieri, M. Co-creating value in urban public policy contexts: A different approach. Land Use Policy 2018, 79, 20-29. [CrossRef]

5. Jarillo, J.C. On strategic networks. Strateg. Manag. J. 1988, 9, 31-41. [CrossRef]

6. Lorenzoni, G. Accordi, reti e vantaggio competitivo; Etas: Milano, Italy, 1992.

7. Saviano, M.; Di Nauta, P.; Montella, M.M.; Sciarelli, F. Managing protected areas as cultural landscapes: The case of the Alta Murgia National Park in Italy. Land Use Policy 2018, 76C, 290-299. [CrossRef]

8. Saviano, M.; Di Nauta, P.; Montella, M.M.; Sciarelli, F. The Cultural Value of Protected Areas as Models of Sustainable Development. Sustainability 2018, 10, 1567. [CrossRef]

9. Sicca, L. La Gestione strategica dell'impresa; Cedam: Padova, Italy, 1998.

10. Berry, L.L. Relationship marketing. In Emerging Perspectives on Service Marketing; Berry, L.L., Shostack, G.L., Upah, G.D., Eds.; American Marketing Association: Chicago, IL, USA, 1983.

11. Grönroos, C. From scientific management to service management: A management perspective for the age of service competition. Int. J. Serv. Ind. Manag. 1994, 5, 5-20. [CrossRef]

12. Morgan, C. Programming from Specifications; Prentice Hall: Upper Saddle River, NJ, USA, 1994.

13. Hagedoorn, J.; Dysters, G. External sources of innovative capabilities: The performance for strategic alliances or mergers and acquisitions. J. Manag. Stud. 2002, 39, 167-188. [CrossRef]

14. Eisenhardt, K.M. Has strategy changed? MIT Sloan Manag. Rev. 2002, 43, 88-91.

15. Lawrence, T.B.; Hardy, C.; Phillips, N. Institutional effects of inter-organizational collaborations: The emergence of proto-institutions. Acad. Manag. J. 2002, 45, 281-290. 
16. Roberts, E.B.; Liu, W.K. Ally or acquire? MIT Sloan Manag. Rev. 2002, 43, 26-34.

17. Maizza, A. (Ed.) I Distretti Agroalimentari nel Contesto Globale. Un'analisi Nel Territorio Pugliese; Franco Angeli: Milano, Italy, 2010.

18. Barile, S.; Di Nauta, P. Viable Systems Approach for territory development. In Contributions to Theoretical and Practical Advances in Management. A Viable Systems Approach (vSa); Barile, S., Bassano, C., Calabrese, M., Confetto, M.G., Di Nauta, P., Piciocchi, P., Polese, F., Saviano, M., Siano, A., Siglioccolo, M., Eds.; ASVSA-Association for Research on Viable Systems, International Printing: Avellino, Italy, 2011.

19. Fait, M. Competitività e sviluppo dei territori del vino; Cacucci: Bari, Italy, 2008.

20. Iaia, L.; Fait, M.; Cavallo, F.; Scorrano, P.; Maizza, A. Experiential marketing per il brand-land dei prodotti tipici: Diventare marchio comunicando il territorio. In Manifattura: Quale futuro? Referred Electronic Conference Proceedings Sinergie, Università di Cassino e del Lazio Meridionale, Italy, 13-14 Novembre 2014; Fondazione Cueim: Verona, Italy, 2014.

21. Maizza, A.; Fait, M.; Scorrano, P. Conditions and Drivers of Competition in a Region: Some Case Histories of Brand-Land Synergism. In Management Innovation and Entrepreneurship: A Global Perspective; Vrontis, D., Sakka, G., Amirkhanpour, M., Eds.; Cambridge Scholars Publishing: Newcastle upon Tyne, UK, 2015.

22. Davenport, T.; Prusak, L. Working Knowledge; Harvard Business School Press: Cambridge, MA, USA, 1998.

23. Lin, H.F. Effects of extrinsic and intrinsic motivation on employee knowledge sharing intentions. J. Inf. Sci. 2007, 33, 135-149. [CrossRef]

24. Stock, J.H.; Watson, M.W. Why has US inflation become harder to forecast? J. Money Credit Bank. 2007, 39, 3-33. [CrossRef]

25. Cummings, J.N. Work groups, structural diversity, and knowledge sharing in a global organization. Manag. Sci. 2004, 50, 352-364. [CrossRef]

26. Pulakos, E.D.; Dorsey, D.W.; Borman, W.C. Hiring for Knowledge-Based Competitio. In Managing Knowledge for Sustained Competitive Advantage; Jackson, S.E., Hitt, M.A., Denisi, A.S., Eds.; Jossey-Bass: San Francisco, CA, USA, 2003; pp. 155-177.

27. Dyer, J.H.; Nobeoka, K. Creating and managing a high-performance knowledge-sharing network: The Toyota case. Strateg. Manag. J. 2000, 21, 345-367. [CrossRef]

28. Di Stefano, G.; Gambardella, A.; Verona, G. Technology push and demand pull perspectives in innovation studies: Current findings and future research directions. Res. Policy 2012, 41, 1283-1295. [CrossRef]

29. Del Giudice, M.; Maggioni, V. Managerial practices and operative directions of knowledge management within inter-firm networks: A global view. J. Knowl. Manag. 2014, 18, 841-846. [CrossRef]

30. Rullani, E. Introduzione al tema: Produzione sostenibile: La nuova stella polare per navigare (a vista) nel mare della crisi. Economia e società regionale 2011, 114, 5-21.

31. Quigley, N.R.; Tesluk, P.E.; Locke, E.A.; Bartol, K.M. A multilevel investigation of the motivational mechanisms underlying knowledge sharing and performance. Organ. Sci. 2007, 18, 71-88. [CrossRef]

32. Baccarani, C.; Golinelli, G.M. L'imprenditore tra imprenditorialità, managerialità, leadership e senso del futuro. Sinergie rivista di studi e ricerche 2011, 71, 7-14.

33. Inkpen, A.C.; Tsang, E.W. Social capital, networks, and Knowledge transfer. Acad. Manag. Rev. 2005, 30, 146-165. [CrossRef]

34. Ahmad, N.; Quadri, N.; Qureshi, M.; Alam, M. Relationship Modeling of Critical Success Factors for Enhancing Sustainability and Performance in E-Learning. Sustainability 2018, 10, 4776. [CrossRef]

35. Gabbay, S.M.; Leenders, R.T.A. (Eds.) Social capital of organizations: From social structure to the management of corporate social capital. In Social Capital of Organizations (Research in the Sociology of Organizations); Emerald Group Publishing Limited: Bingley, UK, 2001; Volume 18, pp. 1-20.

36. Gargiulo, M.; Benassi, M. Trapped in your own net? Network cohesion, structural holes, and the adaptation of social capital. Organ. Sci. 2000, 11, 183-196. [CrossRef]

37. Lusch, R.F.; Vargo, S.L. Service-Dominant Logic: Premises, Perspectives, Possibilities; Cambridge University Press: Cambridge, UK, 2014.

38. Van Den Hooff, B.; De Ridder, J.A. Knowledge sharing in context: The influence of organizational commitment, communication climate and CMC use on knowledge sharing. J. Knowl. Manag. 2004, 8, 117-130. [CrossRef]

39. Adler, P.S.; Kwon, S.W. Social capital: Prospects for a new concept. Acad. Manag. Rev. 2002, 27, 17-40. [CrossRef] 
40. Nahapiet, S.; Ghoshal, S. Social capital, intellectual capital, and the organizational advantage. Acad. Manag. Rev. 1998, 23, 242-266. [CrossRef]

41. Anand, V.; Glick, W.H.; Manz, C.C. Thriving on the knowledge of outsiders: Tapping organizational social capital. Acad. Manag. Executive 2002, 16, 87-101. [CrossRef]

42. Baker, W.E. Achieving Success through Social Capital: Tapping the Hidden Resources in Your Personal and Business Networks; Jossey-Bass: San Francisco, CA, USA, 2000.

43. Nicolini, D. Knowing in Organizations: A Practice-Based Approach; Routledge: Abingdon, UK, 2016.

44. Nonaka, I.; Von Krogh, G.; Voelpel, S. Organizational knowledge creation theory: Evolutionary paths and future advances. Organ. Stud. 2006, 27, 1179-1208. [CrossRef]

45. Chua, A. The influence of social interaction on knowledge creation. J. Intellect. Cap. 2002, 3, 375-392. [CrossRef]

46. Huysman, M.; De Wit, D. Practices of managing knowledge sharing: Towards a second wave of knowledge management. Knowl. Process Manag. 2004, 11, 81-92. [CrossRef]

47. Liu, A.Q.; Besser, T. Social capital and participation in community improvement activities by elderly residents in small towns and rural communities. Rural Sociol. 2003, 68, 343-365. [CrossRef]

48. Requena, F. Social capital, satisfaction and quality of life in the workplace. Soc. Indic. Res. 2003, 61, 331-360. [CrossRef]

49. Chow, W.S.; Chan, L.S. Social network, social trust and shared goals in organizational knowledge sharing. Inf. Manag. 2008, 45, 458-465. [CrossRef]

50. Mcelroy, M.W.; Jorna, R.J.; Van Engelen, J. Rethinking social capital theory: A Knowledge management Perspective. J. Knowl. Manag. 2006, 10, 124-136. [CrossRef]

51. Wasko, M.M.; Faraj, S. Why should I share? Examining social capital and knowledge contribution in electronic networks of practice. MIS Q. 2005, 29, 35-57. [CrossRef]

52. Yli-Renko, H.; Autio, E.; Sapienza, H.J. Social capital, knowledge acquisition, and knowledge exploitation in young technology-based firms. Strateg. Manag. J. 2001, 22, 587-613. [CrossRef]

53. Uphoff, N. Understanding social capital: Learning from the analysis and experience of participation. In Social Capital: A Multifaceted Perspective; Dasgupta, P., Serageldin, I., Eds.; The World Bank: Washington, DC, USA, 2000; pp. 215-249.

54. Bandura, A. Self-efficacy: Toward a Unifying Theory of Behavioral Change. Psychol. Rev. 1977, 84, $191-215$. [CrossRef] [PubMed]

55. Bandura, A. Social cognitive theory of mass communication. In Media Effects: Advances in Theory and Research; Bryant, J., Oliver, M.B., Eds.; Routledge: New York, NY, USA, 2002; pp. 94-124.

56. Bandura, A. Social cognitive theory: An agentic perspective. Annu. Rev. Psychol. 2001, 52, 1-26. [CrossRef]

57. Bandura, A. Social Foundations of Thought and Action: A Social Cognitive Theory; Prentice-Hall: Englewood Cliffs, NJ, USA, 1986.

58. Maddux, J.E. Self-Efficacy Theory. In Self-Efficacy, Adaptation, and Adjustment. The Plenum Series in Social/Clinical Psychology; Maddux, J.E., Ed.; Springer: Boston, MA, USA, 1995; pp. 3-33.

59. Sherer, M.; Maddux, J.E.; Mercandante, B.; Prentice-Dunn, S.; Jacobs, B.; Rogers, R.W. The self-efficacy scale: Construction and validation. Psychol. Rep. 1982, 51, 663-671. [CrossRef]

60. Rolstadås, A. (Ed.) Benchmarking-Theory and Practice; Springer: Berlin, Germany, 2013.

61. Dalkir, K. Knowledge Management in Theory and Practice, 2nd ed.; MIT Press: Cambridge, MA, USA, 2011.

62. Leenders, R.T.A.; Gabbay, S.M. (Eds.) Corporate Social Capital and Liability; Springer Science \& Business Media: New York, NY, USA, 2013.

63. Amhed, S.A.; D'astous, A.; El Adraoui, M. Country-of-origin effects on purchase managers' product perceptions. Ind. Mark. Manag. 1994, 23, 323-332.

64. Bilkey, W.J.; Nes, E. Country-of-Origin Effects on Product Evaluations. J. Int. Bus. Stud. 1982, 13, 89-99. [CrossRef]

65. Di Nauta, P. Il settore agroalimentare in Italia fra tradizione ed innovazione. Uno sguardo alla Capitanata; WIP Edizioni: Bari, Italy, 2013.

66. Hong, S.T.; Wyer, R.S. Effects of Country-of-Origin and Product-Attribute Information Processing Perspective. J. Consum. Res. 1989, 16, 175-187. [CrossRef]

67. Johnasson, J.K.; Douglas, S.P.; Nonaka, I. Assessing the Impact of Country of Origin on Product Evaluations: A New Methodological Perspective. J. Mark. Res. 1985, 22, 388-396. [CrossRef] 
68. Maheswaran, D. Country of Origin as a Stereotype: Effects of Consumer Expertise and Attribute Strength on Product Evaluations. J. Consum. Res. 1994, 21, 354-365. [CrossRef]

69. Schmitt, B.H. Experiential Marketing; The Free Press: New York, NY, USA, 1999.

70. Mastroberardino, P. Contributi sul tema dei sistemi turistici locali; Edizioni Scientifiche Italiane: Torino, Italy, 2004.

71. Scorrano, P. Communicate global-Consume local. Le produzioni agroalimentari tipiche nel web. Sinergie 2013, 92, 25-48.

72. Siano, A.; Confetto, M.G.; Vollero, A. Governance-struttura-sistema: Un modello di management della comunicazione per il marketing territoriale. In Proceedings of the 7th International Congress Marketing Trends Proceedings, Università Cà Foscari, Venezia, Italy, 17-19 Gennaio 2008; pp. 1-38.

73. Siano, A. Conoscenza e risorse monetarie: Analogie e principi di management convergenti. Sinerg. Ital. J. Manag. 2011, 76, 175-190.

74. XV Rapporto Ismea-Qualivita 2016. Available online: http://www.ismea.it/flex/cm/pages/ServeBLOB. php/L/IT/IDPagina/10226 (accessed on 10 December 2017).

75. Golinelli, G.M. L'approccio Sistemico al Governo Dell'impresa. Valorizzazione delle Capacità, Rapporti Intersistemici e Rischio Nell'azione di Governo; Cedam: Padova, Italy, 2002.

76. Barile, S.; Quattrociocchi, B.; Calabrese, M.; Iandolo, F. Sustainability and the Viable Systems Approach: Opportunities and Issues for the Governance of the Territory. Sustainability 2018, 10, 790. [CrossRef]

77. Bagnasco, A. Il capitale sociale nel capitalismo che cambia. Stato e Mercato 2002, 22, 271-304.

78. Coleman, J.S. Social capital in the creation of human capital. Am. J. Sociol. 1988, 94, 95-120. [CrossRef]

79. La Valle, D. Il capitale sociale nella teoria dello scambio. Stato e Mercato 2002, 22, 305-334.

80. Lyn, N. Social Capital. A Theory of Social Structure and Action; Cambridge University Press: Cambridge, UK, 2001.

81. Hsu, M.H.; Wang, E.T. Understanding knowledge sharing in virtual communities: An integration of social capital and social cognitive theories. Decis. Support Syst. 2006, 42, 1872-1888.

82. Kolekofski, K.E., Jr.; Heminger, A.R. Beliefs and attitudes affecting intentions to share information in an organizational setting. Inf. Manag. 2003, 40, 521-532. [CrossRef]

83. Lesser, E.L. Leveraging social capital in organizations. In Knowledge and Social Capital: Foundations and Applications; Elsevier: Amsterdam, The Netherlands, 2000; Volume 3, p. 16.

84. Zhang, Y.; Hiltz, S.R. Factors that influence online relationship development in a knowledge sharing community. In Proceedings of the AMCIS Proceedings, Tampa, FL, USA, 4-6 August 2003; Volume 53.

85. Bourdieu, P. Le capital social: Notes provisoires. Actes de la Recherche en Sciences Sociales 1980, 31, 2-3. [CrossRef]

86. Van Leeuwen, C.; Seguin, G. The concept of terroir in viticulture. J. Wine Res. 2006, 17, 1-10. [CrossRef]

87. De Leeuw, E.D. Choosing the method of data collection. In International Handbook of Survey Methodology; de Leeuw, E.D., Hox, J.J., Dillman, D.A., Eds.; Taylor \& Francis Group: New York, NY, USA, 2008.

88. Singleton, R., Jr.; Straits, B.C.; Straits, M.M.; McAllister, R.J. Approaches to Social Research; Oxford University Press: Oxford, UK, 1988.

89. Bracalente, B.; Cossignani, M.; Mulas, A. Statistica Aziendale; McGraw-Hill: Milano, Italy, 2009.

90. Akaka, M.A.; Vargo, S.L.; Lusch, R.F. The complexity of context: A service ecosystems approach for international marketing. J. Mark. Res. 2013, 21, 1-20. [CrossRef]

91. Lusch, R.F.; Vargo, S.L. Service-dominant logic: A necessary step. Eur. J. Mark. 2011, 45, 1298-1309. [CrossRef]

92. Vargo, S.L.; Wieland, H.; Akaka, M.A. Innovation through institutionalization: A service ecosystems perspective. Ind. Mark. Manag. 2015, 44, 63-72. [CrossRef]

(C) 2019 by the authors. Licensee MDPI, Basel, Switzerland. This article is an open access article distributed under the terms and conditions of the Creative Commons Attribution (CC BY) license (http:/ / creativecommons.org/licenses/by/4.0/). 